\title{
SINTESIS KATALIS LOGAM BERPENYANGGA DENDRIMER POLIGLISEROL BERBASIS TURUNAN KELAPA SAWIT
}

\section{(THE SYNTHESIS OF METAL CATALYST SUPPORTED DENDRIMER POLYGLYCEROL BASED DERIVATIVE PALM OIL)}

\author{
Dwinna Rahmi, Retno Yunilawati, dan Arief Riyanto \\ Balai Besar Kimia dan Kemasan, Kementerian Perindustrian RI \\ JI. Balai Kimia I Pekayon, Pasar Rebo, Jakarta Timur \\ E-mail: dwinna2002@yahoo.com
}

Received: 5 Juli 2016; revised: 15 Agustus 2016; accepted: 29 Agustus 2016

\begin{abstract}
ABSTRAK
Pembuatan katalis logam dengan payangga dendrimer poligliserol telah dilakukan dengan beberapa tahapan proses yaitu polimerisasi, tosilasi aminasi dan pengikatan logam ( $\mathrm{Ni}$ atau $\mathrm{Cu}$ ). Penelitian ini dimaksudkan untuk meningkatkan niai tambah gliserol turunan kelapa sawit serta mendapatkan katalis dengan peyangga bahan agro lokal. Produk poligliserol amin ditandai dengan munculnya puncak pada spectrum FTIR yang mengindikasikan adanya gugus fungsi $\mathrm{C}=\mathrm{O}$ atau $\mathrm{C}-\mathrm{O}-\mathrm{O}$ dan $\mathrm{N}=\mathrm{O}$. Dari spektrum massa $L C-M S$ diketahui bahwa poligliserol dihasilkan pada menit ke 5,7. Selanjutnya dari percobaan penggunaan katalis Ni ini untuk proses hidrogenasi menghasilkan minyak terhidrogenasi dengan slip melting point pada $33^{\circ} \mathrm{C}$ dan bilangan peroksida sebesar 0,25 mek/kg.
\end{abstract}

Kata kunci : Dendrimer poligliserol, Katalis logam, Hidrogenasi

\begin{abstract}
Polyglycerol dendrimer was synthesized through the glycerol polymerization with the added base catalyst. A catalyst with polyglycerol dendrimer as supporting agent was made through a process tocilation, amidation and attactent $\mathrm{Ni}$ and $\mathrm{Cu}$. The analysis results by FTIR has showed a products has functional group of $\mathrm{C}=\mathrm{O}$ or $\mathrm{C}-\mathrm{O}-\mathrm{C}$ and $N=O$. Moreover, a mass spectrum of LC-MS indicated polyglycerol appeared at 5.7 minutes. The result of hidrogenated-oil process which produced catalyst Ni polyglycerol dendrimer were hyrogenated oil with slip melting point in $33^{\circ} \mathrm{C}$ and peroxide value $0.25 \mathrm{mek} / \mathrm{kg}$.
\end{abstract}

Key words : Polyglycerol dendrimer, Metal catalyst, Hydrogenation

\section{PENDAHULUAN}

Dalam proses kimia, katalis adalah bahan yang ditambahkan dengan jumlah sedikit dan sangat berperan (Wijngarden et al. 2000). Pentingnya katalis ditunjukkan oleh kenyataan bahwa lebih dari $75 \%$ proses produksi bahan kimia di industri disintesis dengan bantuan katalis. Kebutuhan katalis Indonesia mencapai 2000 ton/tahun dengan masa aktif 1 tahun sampai dengan 2 tahun. Kebutuhan katalis yang cukup besar ini sebagian besar dipenuhi dengan katalis impor karena sampai saat ini masih terbatasnya industri katalis lokal (Lestari 2006), pada tahun 2014 dimulai produksi katalis untuk kebutuhan PT. Pertamina (Republika 2015).

Gliserol merupakan produk samping utama proses industri oleokimia dimana secara ekonomi sangat berperan karena jumlahnya yang banyak. Sejak produksi biodisel dari minyak nabati digalakkan lebih dari satu dekade, kira-kira 2 ton gliserol ada di pasaran (Ciriminna et al. 2014). Ditambah dengan pertumbuhan produk asam lemak, fatty alcohol, produk gliserol semakin meningkat dari tahun ke tahun. Gliserol ada berbagai tipe tergantung dari kemurniannya. Kemurnian gliserol ditentukan oleh sifat fisik seperti higroskopis, tidak bewarna, tidak berbau, kental, rendah titik didih, dan spesifikasi kimianya seperti tidak beracun, emolien dan larut dalam air. Gliserol mentah mempunyai kemurnian sekitar $86 \%$. Pada umumnya gliserol mentah masih mengandung metanol dan asam lemak bebas yang tinggi. Gliserol yang tersedia 
dipasar pada umumnya mempunyai kemurnian $99,5 \%$. Penggunaan gliserol sangat banyak sebagai bahan tambahan produksi turunan oleokimia lainnya seperti bahan pengemulsi makanan, poliuretan, obat dan kosmetik. Upaya yang sudah dilakukan untuk mengembangkan produk dari gliserol adalah glycidol (2,3epoxypropanol), gliserol karbonat, dan poligliserol (Gunstone and Heming 2004). Poligliserol ada bermacam-macam yaitu merupakan polimer linear, bercabang dan star polimer. Star polimer dikenal juga dengan nama dendrimer (Trollsås and Hedrick 1998).

Dendrimer berbasis uniform molekul, multifungsi permukaan yang biasanya reaktif dan dengan adanya rongga pada internal berpotensi diterapkan diberbagai bidang. Bentuk yang spesifik dan unik ini menjadikan dendrimer dapat diterapkan pada bidang farmasi (Cheng et al. 2007) dan non farmasi (Klajnert and Bryszewska 2000). Salah satu penerapan dibidang non farmasi adalah sebagai katalisis. Dengan keunikan struktur dendrimer dapat berfungsi sebagai penyangga katalis dengan reaksi kompleks dengan logam yang bersifat selektif (Hajji and Haag 2006, Jiang and Gao 2006). Dendrimer poligliserol adalah dendrimer yang berbasis gliserol. Salah satu fungsinya adalah sebagai penyangga katalis karena gugus fungsi dapat mengikat logam seperti $\mathrm{Ni}, \mathrm{Cu}, \mathrm{Pt}$ dan lain-lain. Selama ini katalis logam dibuat dengan peyangga mineral seperti Ni (Purwanto, 2010). Mineral termasuk bahan yang tidak dapat terbarukan, dilain pihak ketersediaan bahan yang dapat diperbarui seperti bahan agro tersedia banyak di Indonesia. Salah satu bahan agro adalah turunan kelapa sawit seperti gliserol.

Ketersediaan gliserol dapat dilihat dari tumbuhnya industri biodisel dan industri oleokimia. Gliserol merupakan hasil samping proses pembuatan biodiesel menggunakan proses transesterifikasi (Rahayu 2005) dan proses hidrolisis minyak nabati. Karena ketersediaan gliserol yang banyak, pada penelitian ini dilakukan pembuatan katalis yang berbasis turunan kelapa sawit.

\section{BAHAN DAN METODE}

\section{Bahan}

Bahan yang digunakan pada penelitian ini adalah gliserol yang diperoleh dari PT. Ecogreen, gas nitrogen dan gas hidrogen dari PT. Windu, $\mathrm{KOH}$, piridin, p-toluensulfonil klorida/tosil klorida $\left(\mathrm{CH}_{3} \mathrm{CH}_{4} \mathrm{SO}_{2} \mathrm{Cl}\right)$, dietil amina $\left(\mathrm{C}_{4} \mathrm{H}_{11} \mathrm{~N}\right), \mathrm{Ni}\left(\mathrm{NO}_{3}\right)_{2} 6 \mathrm{H}_{2} \mathrm{O}, \mathrm{Cu}\left(\mathrm{CO}_{3}\right)_{2} 3 \mathrm{H}_{2} \mathrm{O}$ dari PT. Merck dan Minyak Kelapa dari Barco
Alat-alat yang digunakan adalah Stand Floor Reactor kapasitas $1 \mathrm{~L}$ dari PARR USA dan Pressure Products Industries (PPI) yang dilengkapi dengan pengatur suhu, tekanan, dan aliran gas nitrogen, gas ammonia dan gas hidrogen serta pengaduk. Hot plate stirrer dari Thermo Scientific serta alat gelas dari pyrex. Alat instrumen untuk uji struktur kimia produk dilakukan menggunakan liquid chromatographymass spectrometry (LC-MS) Mariner Biospectrometry dengan binary pump dan kolom Supelco $5 \mu$ C18, $250 \times 2 \mathrm{~mm}$ i.d., dan Fourierd Transform Infrared Spectroscopy (FTIR). Sedangkan karakteristik permukaan katalis diuji dengan Scanning Electron Microscopy (SEM) dan kandungan material katalis dengan $X$-ray Diffraction (XRD).

\section{Metode}

Beberapa tahapan yang dilakukan untuk menghasilkan katalis berpenyangga dedrimer poligliserol metal poligliserol (M-PG) yaitu; polimerisasi gliserol menjadi poligliserol/PG-OH, aminasi $\mathrm{PG}-\mathrm{OH}$ menjadi $\mathrm{PG}-$ amin/PG-NR $\mathrm{N}_{2}$, sintesis katalis dari $\mathrm{PG}-\mathrm{NR}_{2}$ menjadi katalis PG-M.

Pembuatan dendrimer poligliserol diambil dari metode penelitian terdahulu (Rahmi et al. 2014). Sebanyak $700 \mathrm{~g}$ gliserol dimasukkan kedalam reaktor PARR lalu ditambahkan katalis $\mathrm{KOH} 7 \mathrm{~g}$ dan pemanasan selama 20 jam pada suhu $250^{\circ} \mathrm{C}$ sambil diaduk dengan kecepatan pengadukan $200 \mathrm{rpm}$. Produk PG-OH yang dihasilkan kemudian dianalisa dengan FTIR untuk melihat gugus fungsi yang terbentuk. Untuk pembuatan penyangga katalis, tosil klorida (TCl) dalam piridin ditambahkan kedalam PG-OH dengan perbandingan mol TCl dan PG$\mathrm{OH}$ sebesar 2 : 1, kemudian diaduk menggunakan pengaduk magnet pada suhu ruang selama 16 jam. Produk yang dihasilkan dituang kedalam air dingin yang sudah diberi $\mathrm{HCl} 10 \%$ dan diaduk. Selanjutnya dilakukan ekstraksi produk PG-O-Tos dengan kloroform. Ekstrak kloroform yang sudah dihilangkan pelarutnya kemudian diaminasi dengan menambahkan $10 \mathrm{~mL}$ dietilamin $\left(\mathrm{NHR}_{2}\right)$ dan diaduk menggunakan pengaduk magnet selama 24 jam. Untuk mendapatkan katalis PG-M maka ditambahkan larutan $\mathrm{Cu}\left(\mathrm{NO}_{3}\right)_{2} \cdot 3 \mathrm{H}_{2} \mathrm{O}$ atau $\mathrm{Ni}\left(\mathrm{NO}_{3}\right)_{2} .6 \mathrm{H}_{2} \mathrm{O} 10 \%$ kedalam PG-NR2 lalu stirer selama 1 jam. Endapan berupa katalis PG-Cu atau PG-Ni yang diperoleh diambil dan dikeringkan.

Percobaan penerapan katalis PG-Ni dilakukan dengan proses hidrogenasi minyak kelapa menjadi minyak kelapa terhidrogenasi. Katalis PG-Ni sebanyak $1 \%$ dimasukkan kedalam reaktor PPI lalu purging dengan 
nitrogen selama 30 menit pada suhu $200^{\circ} \mathrm{C}$. Kemudian dilanjutkan dengan proses reduksi dengan mengalirkan gas hidrogen dengan flowrate kurang lebih 0,2 L/menit selama 3 jam. Setelah itu sampel dimasukkan kedalam reaktor dan dihidrogenasi dengan gas $\mathrm{H}_{2}$ pada tekanan 80 bar suhu $200^{\circ} \mathrm{C}$ selama 60 menit.

\section{HASIL DAN PEMBAHASAN}

\section{Poligliserol (PG-OH)}

Polimerisasi gliserol menjadi poligliserol dilakukan dengan kehadiran katalis basa untuk membentuk struktur dendrimer. Reaksi terjadi karena adanya serangan nukleopilik ke gugus hidroksi. Poligliserol dendrimer mempunyai struktur bercabang dan banyak gugus hidroksi tiap ujung strukturnya (de Queiroz et al. 2006). Gambar 1 menampilkan spektrum FTIR dari produk dendrimer poligliserol. Beberapa puncak terlihat keluar pada spektrum ini. Spektrum berupa lembah yang luas pada bilangan gelombang antara $3500 \mathrm{~cm}^{-1}$ sampai dengan $3700 \mathrm{~cm}^{-1}$ mengindikasikan adanya gugus hidroksi $(\mathrm{O}-\mathrm{H})$. Spektrum yang keluar adalah pada bilangan gelombang tinggi, sedangkan bilangan gelombang untuk ikatan hidrogen pada $\mathrm{OH}$ adalah pada bilangan gelombang $3400 \mathrm{~cm}^{-1}$ sampai dengan $3200 \mathrm{~cm}^{-1}$ tergantung kekuatan dari ikatannya yaitu kemampuan membentuk intra dan inter-molekul dari ikatan hidrogen oleh kelompok OH (Mamiński et al. 2011). Pada bilangan gelombang antara $2600 \mathrm{~cm}^{-1}$ sampai dengan $2700 \mathrm{~cm}^{-1}$ merupakan spektrum tajam dengan terbelah dibagian ujung mengindikasikan adanya gugus $\mathrm{C}-\mathrm{H}$.

Karakterisasi dendrimer polyamidoamine (PAMAM) puncak pada bilangan gelombang
$2700 \mathrm{~cm}^{-1}$ sampai dengan $2940 \mathrm{~cm}^{-1}$ mengindikasikan adanya gugus $\mathrm{C}-\mathrm{H}$ (Kesharwani and Jain 2014). Selanjutnya spektrum kecil pada bilangan gelombang $1600 \mathrm{~cm}^{-1}$ mengindikasikan adanya gugus $\mathrm{C}=\mathrm{O}$ atau O-C-O. Spektrum ini diperkuat dengan adanya spektrum yang tajam pada bilangan gelombang $1100 \mathrm{~cm}^{-1}$ dan $1200 \mathrm{~cm}^{-1}$ yang mengindikasikan adanya struktur C-O-C (Boudou et al. 2013). Pada PAMAM juga keluar puncak pada bilangan gelombang $1595 \mathrm{~cm}^{-1}$ (Kesharwani, et al. 2014). Dari spektrum FTIR ini terlihat adanya struktur yang mempunyai gugus $\mathrm{O}-\mathrm{H}$ diujung ikatan struktur dan gugus $\mathrm{O}-\mathrm{C}-\mathrm{O}$ dan C-O-C di tengah ikatan struktur poligliserol (Rahmi et al.2014). Gugus hidroksi dengan permukaan yang paling luas mengindikasikan bahwa gugus $\mathrm{O}-\mathrm{H}$ mempunyai persentase yang lebih tinggi dibanding gugus yang lain.

Dari perkiraan gugus fungsi selanjutnya dilakukan analisa berat molekul dengan $L C-M S$. Dari hasil analisa menggunakan LC-MS dihasilkan beberapa puncak kromatogram (Gambar 2). Dari kromatogram ini dapat diketahui bahwa produk belum homogen, ada 3 puncak yaitu pada waktu retensi 1,8 menit; 2,4 menit; dan 5,7 menit.

Ada beberapa struktur yang akan terbentuk dari proses polimerisasi ini yaitu gliserol, digliserol, trigliserol, tetragliserol dan multigliserol. Digliserol dan seterusnya di namai poligliserol, sementara dendrimer yang merupakan poligliserol dengan banyak cabang yaitu terdiri dari 1 inti dan 3 cabang. Gliserol $\left(\mathrm{C}_{3} \mathrm{O}_{3} \mathrm{H}_{8}\right)$ dengan $\mathrm{m} / \mathrm{z}$ 92, $\mathrm{m} / \mathrm{z}$ digliserol $\left(\mathrm{C}_{6} \mathrm{O}_{5} \mathrm{H}_{14}\right)$ 166, m/z $\left(\mathrm{C}_{9} \mathrm{O}_{7} \mathrm{H}_{20}\right)$ trigliserol 240, tetragliserol $\left(\mathrm{C}_{11} \mathrm{O}_{9} \mathrm{H}_{26}\right) 302$ dan multigliserol $\left(\mathrm{C}_{29} \mathrm{O}_{21} \mathrm{H}_{50}\right) \mathrm{m} / \mathrm{z} 734$.

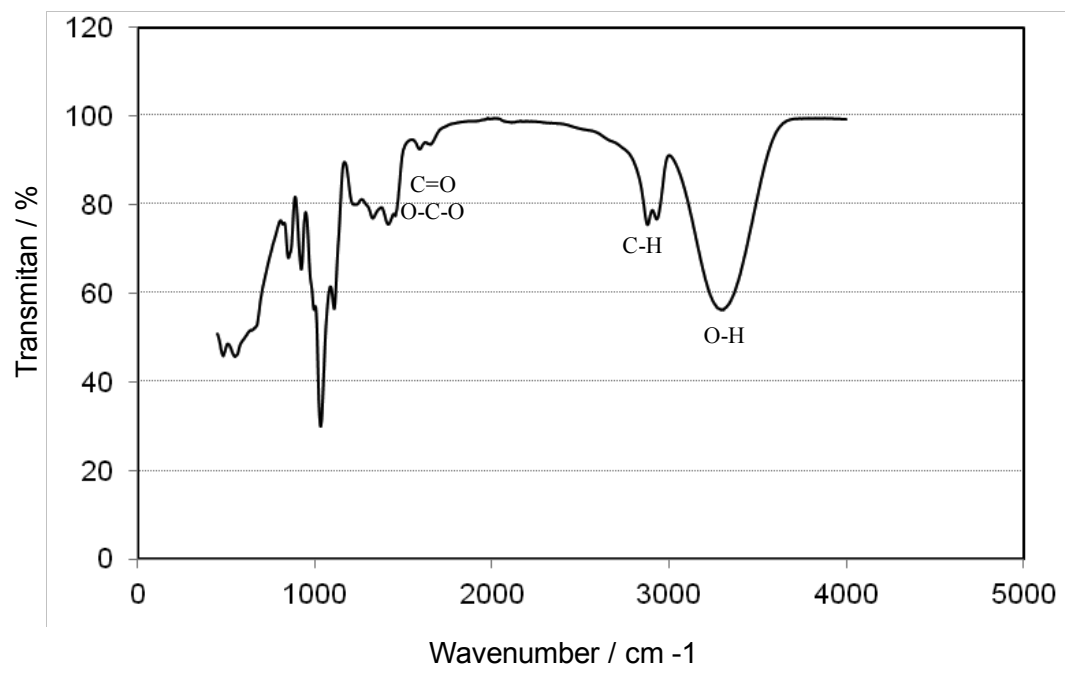

Gambar 1. Spektrum FTIR dendrimer poligliserol 
Dari spektrum massa produk poligliserol didapatkan menit 1,8 puncak utama terlihat ion positif $[\mathrm{M}+2 \mathrm{Na}]^{+}$pada berat molekul $(\mathrm{m} / \mathrm{z}) 137$, $[2 \mathrm{M}+4 \mathrm{H}]^{+},[\mathrm{M} 4+\mathrm{Na}]^{+}$pada $\mathrm{m} / \mathrm{z}$ masing-masing 236 dan 325. Spektrum pada menit ke 2,4 terlihat ion positif [2M] pada $\mathrm{m} / \mathrm{z} 166,[2 \mathrm{M}+\mathrm{Na}]^{+}$ pada $\mathrm{m} / \mathrm{z} 189,[2 \mathrm{M}+2 \mathrm{~K}+\mathrm{H}]^{+} \mathrm{m} / \mathrm{z} 245$ dan ion negatif $[2 \mathrm{M}+2 \mathrm{~K}+\mathrm{H}]^{+}$pada $\mathrm{m} / \mathrm{z} 319$. Sedangkan pada menit ke 5,7 terlihat puncak utama terlihat pada $\mathrm{m} / \mathrm{z} 285$ sebagai ion negatif $\left[4 \mathrm{M}-\mathrm{Cl}^{-}-3 \mathrm{H}\right]^{-}$dan $\left[4 \mathrm{M}+\mathrm{CO}_{2}^{-}-2 \mathrm{H}\right]^{-}$pada $\mathrm{m} / \mathrm{z}$ 256, serta ion positif pada $\mathrm{m} / \mathrm{z} 304[4 \mathrm{M}+2 \mathrm{H}]^{+}$.

Berdasarkan nilai $\mathrm{m} / \mathrm{z}$ dari spektrum massa pada Gambar 3a dengan rumus kimia $\mathrm{C}_{3} \mathrm{O}_{3} \mathrm{H}_{8}$ maka puncak pertama yang keluar pada kromatogram yang diperkirakan sebagai senyawa gliserol. Pada puncak berikutnya yaitu keluar pada menit ke 2,4 dengan rumus kimia $\mathrm{C}_{6} \mathrm{O}_{5} \mathrm{H}_{14}$ sebagai senyawa digliserol. Sedangkan puncak yang keluar pada menit ke 5,7 dengan rumus kimia $\mathrm{C}_{11} \mathrm{O}_{9} \mathrm{H}_{26}$ yang diperkirakan sebagai tetragliserol. Tetragliserol ini sebagai dendrimer terdiri dari 1 gugus gliserol sebagai inti dan 3 gugus gliserol sebagai kulit.

\section{Katalis Berpenyangga Poligliserol (Katalis PG-M)}

Penyangga katalis disintesis dari poligliserol dengan terlebih dahulu melalui proses tosilasi gugus hidroksi dengan pelarut piridin (Slagt et al. 2004). PG-Tos diekstrak dengan kloroform, lalu ekstrak poligliserol-tos diaminasi dengan dietilamin. PG-amin ini lalu direaksikan dengan logam yaitu $\mathrm{Ni}$ dan $\mathrm{Cu}$ untuk mendapatkan katalis. Katalis dihasilkan dari reaksi antara hidrokarbon dengan logam membentuk organometal. Organometal yang dihasilkan adalah organocopper dan organonickle dimana PG-amin sebagai hidrokarbon. Ikatan yang terjadi adalah ikatan kovalen dengan organometal untuk menghasilkan katalis (Hajji and Haag 2006). PGamin sebagai ligan dengan gugus hidroksi terikat dengan logam yang teroksidasi (Hajji and Haag 2006). Gugus hidroksi dan gugus fungsi lainnya dapat dilihat pada Gambar 4. Adanya puncak pada bilangan gelombang $3400 \mathrm{~cm}^{-1}$ menandakan adanya gugus $\mathrm{O}-\mathrm{H}$ katalis $\mathrm{Ni}$ maupun katalis $\mathrm{Cu}$ yang berasal dari poligliserol. Puncak tajam pada bilangan gelombang $1652 \mathrm{~cm}^{-1}$ sampai dengan $1648 \mathrm{~cm}^{-1}$ dan puncak $1303 \mathrm{~cm}^{-1}$ mengindikasikan adanya gugus amin berikatan dengan $\mathrm{C}=\mathrm{O}$ (Schmitt and Flemming 1998).

Pada katalis $\mathrm{Ni}$ puncak pada bilangan gelombang amin terlihat jelas sedangkan puncak yang keluar dari katalis Cu kurang tajam. Hal ini terjadi karena permukaan katalis $\mathrm{Ni}$ yang lebih seragam dibanding katalis $\mathrm{Cu}$. Dari hasil foto dengan SEM juga terlihat bahwa katalis $\mathrm{Ni}$ bentuknya lebih seragam dan konsisten. $\mathrm{Cu}$ yang berikatan dengan gugus hidroksi bersifat amfoteric (larut dalam asam dan basa) sehingga bentuknya menjadi tidak seragam

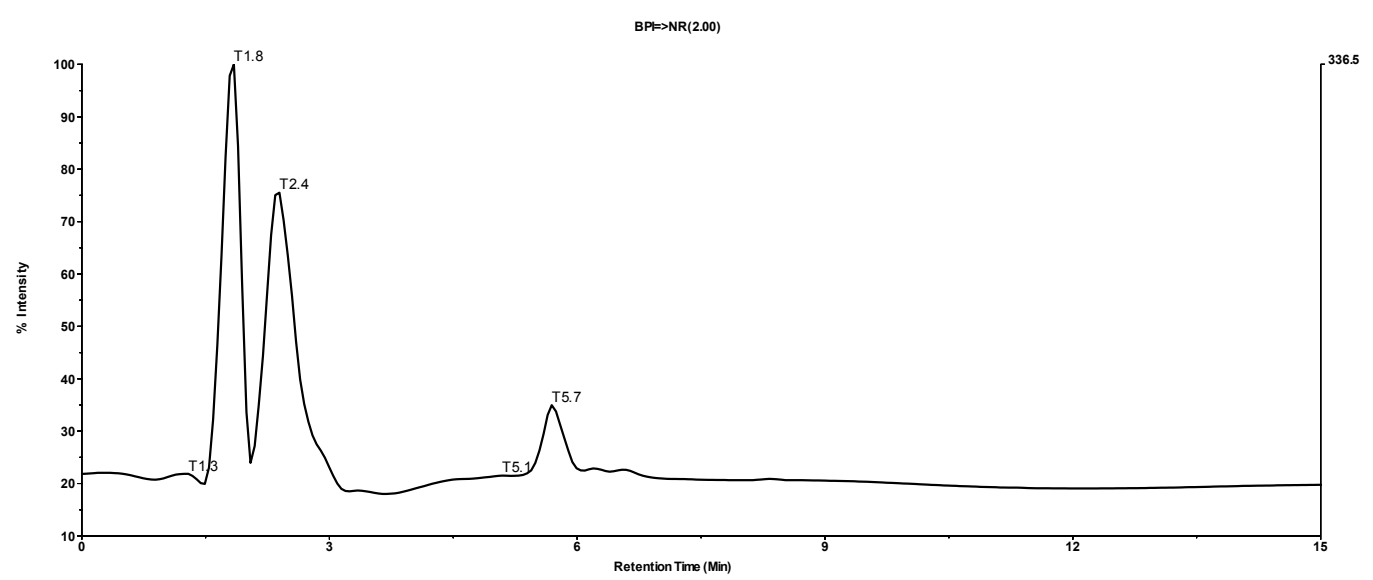

Gambar 2. Kromatogram LC-MS dari dendrimer poligliserol 

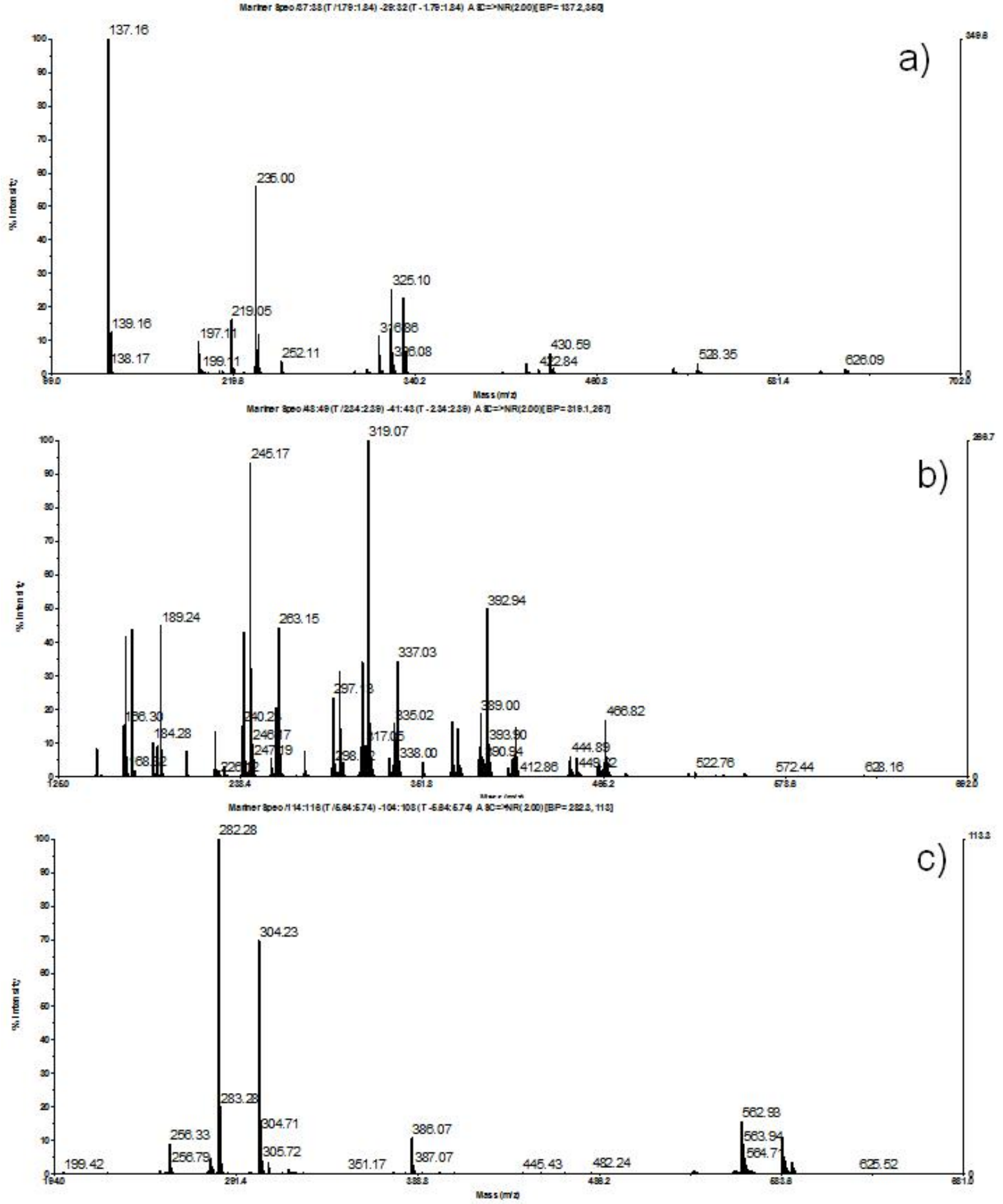

Gambar 3. Spektrum massa produk poligliserol a) T 1,8 menit b) T 2,4 menit c) T 5,7 menit 


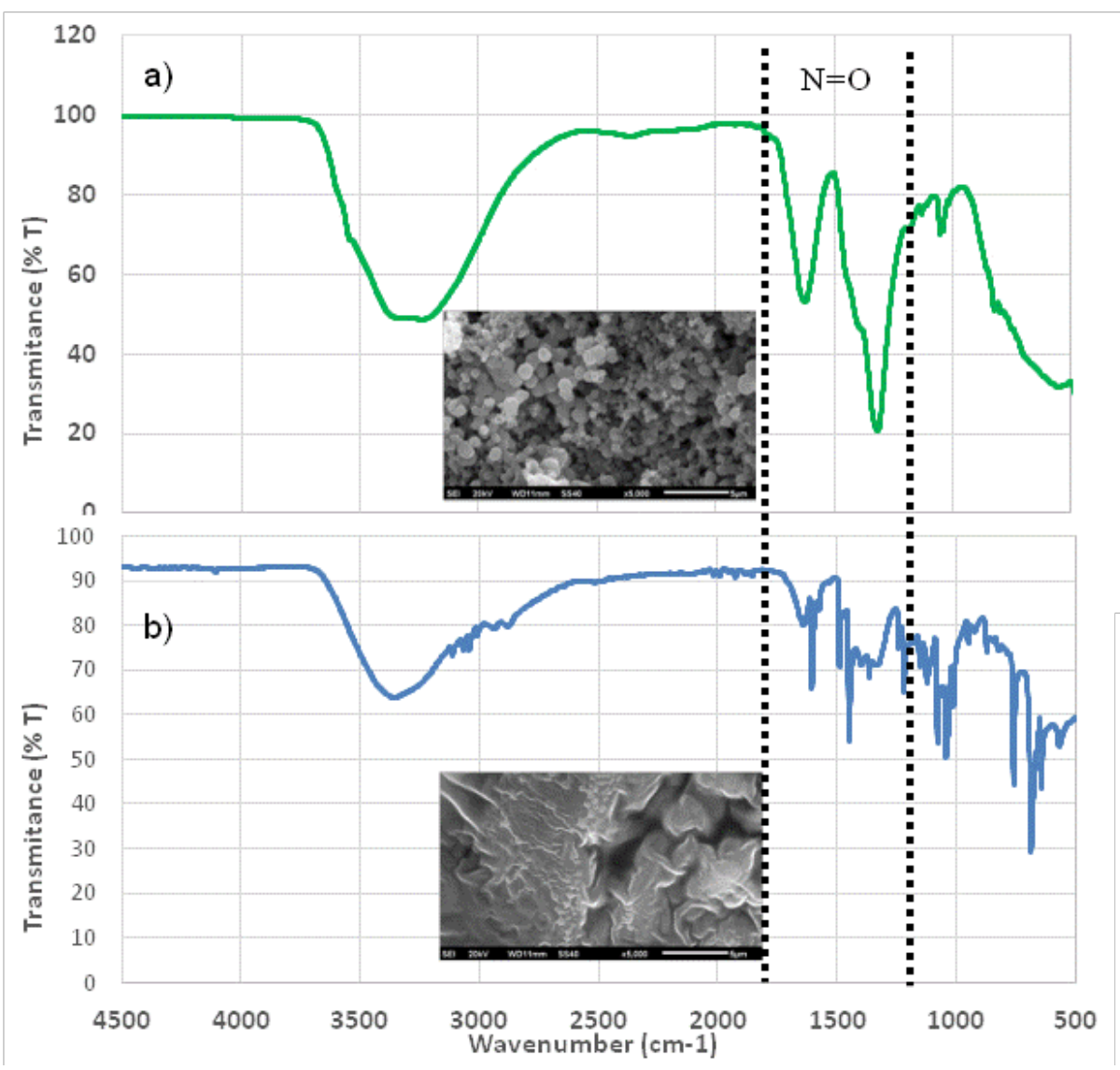

Gambar 4. Spektrum FTIR katalis dan foto permukaan dengan SEM a) katalis PG-Ni dan b) katalis PG-Cu

Dari hasil analisa komposisi kandungan material dalam katalis diperoleh hasil seperti pada Tabel 1. Katalis PG-Ni mengandung $5,58 \%$ logam $\mathrm{Ni}$ sedangkan katalis PG-Cu mengandung 4,95 \% logam $\mathrm{Cu}$. Hidrokarbon (CHON) berupa PG-amin untuk katalis PG-Ni sebanyak 94,3\%, CHON katalis PG-Cu lebih rendah yaitu $85,7 \%$. Dari hasil ini terlihat bahwa katalis PG-Cu mengandung $\mathrm{Cl}$ sebesar 8,8\% dan $\mathrm{S} 0,27 \%$. Pada katalis PG-Cu ada $\mathrm{S}$ dan $\mathrm{Cl}$ yang jumlahnya cukup besar bisa disebabkan reaksi yang belum sempurna antara tosilat dengan dietilamina sehingga masih ada tosil klorida nya $(\mathrm{S}, \mathrm{Cl})$. Hal ini yang menyebabkan bentuk katalis (Gambar 4b) tidak berbentuk. Sementara pada katalis PG-Ni hanya mengandung $0,08 \% \mathrm{Cl}$ dan mengandung logam lain dalam jumlah sedikit $<0,02 \%$ sehingga permukaan katalis lebih bulat dan seragam (Gambar 4a).

\section{Hidrogenasi dengan Katalis PG-Ni}

Katalis PG-Ni selanjutnya diaplikasikan pada proses hidrogenasi minyak kelapa (CNO) untuk melihat peran dari katalis yang dibuat.
Kondisi proses adalah pada suhu $200^{\circ} \mathrm{C}$, tekanan 100 bar, reduksi selama 3 jam pada suhu $200^{\circ} \mathrm{C}$ dan hidrogenasi 1 jam (Rahmi et al. 2015). Dengan kondisi yang sama dilakukan juga tanpa penambahan katalis. Produk yang dihasilkan berupa minyak kelapa terhidrogenasi (CNO-H) dapat dilihat pada Gambar 5b. Produk $\mathrm{CNO}-\mathrm{H}$ dengan katalis PG-Ni berupa lemak padat dan berwarna putih. Lemak padat terjadi karena hampir semua ikatan rangkap yang ada pada minyak kelapa menjadi jenuh dengan reaksi hidrogenasi. Sebaliknya hidrogenasi minyak tanpa penambahan katalis tidak dapat mengubah wujud dari minyak menjadi lemak padat (Gambar 5a).

Hasil analisa mutu yaitu dengan parameter slip melting point, kadar air, dan bilangan peroksida dapat dilihat pada Tabel 2 . Hasil analisa dibandingkan dengan standar industri (salah satu industri penghasil CNO terhidrogenasi). Dihasilkan hampir semua parameter memenuhi standar industri kecuali kandungan air masih lebih tinggi dari standar yaitu lebih tinggi $0,05 \%$. Hal ini dapat diatasi dengan melakukan optimalisasi kondisi proses. 
Tabel 1. Komposisi kandungan material dalam katalis Ni dan katalis $\mathrm{Cu}$

\begin{tabular}{ccc}
\hline Material & Katalis PG-Ni / \% & Katalis PG-Cu / \% \\
\hline $\mathrm{Al}$ & 0 & 0,04 \\
$\mathrm{Si}$ & 0 & 0,09 \\
$\mathrm{P}$ & 0 & 0,26 \\
$\mathrm{~S}$ & 0 & 0,27 \\
$\mathrm{Cl}$ & 008 & $\mathbf{8 , 8 0}$ \\
$\mathrm{K}$ & 0 & 0,04 \\
$\mathrm{Ca}$ & 0,02 & 0,03 \\
$\mathrm{Cr}$ & 0,004 & 0 \\
$\mathrm{Fe}$ & 0,003 & 0 \\
$\mathrm{Ni}$ & $\mathbf{5 , 5 8}$ & 0 \\
$\mathrm{Cd}$ & 0,03 & 0 \\
$\mathrm{Cu}$ & 0 & $\mathbf{4 , 9 5}$ \\
$\mathrm{Tb}$ & 0 & 0,003 \\
$\mathrm{CHON}$ & $\mathbf{9 4 , 3}$ & $\mathbf{8 5 , 7}$ \\
\hline
\end{tabular}

Tabel 2. Hasil analisa mutu produk CNO terhidrogenasi

\begin{tabular}{lccc}
\hline \multicolumn{1}{c}{ Parameter } & Satuan & Standar & CNO terhidrogenasi \\
\hline Penampakan & - & Jernih ketika meleleh & Jernih \\
Bau & - & Netral & Netral \\
Slip melting point & \multicolumn{1}{c}{ C } & $30-34$ & 33 \\
Kadar air & $\%$ & Maks. 0,05 & 0,1 \\
Bilangan peroksida & Mek/kg & Maks. 1,0 & 0,25 \\
\hline
\end{tabular}
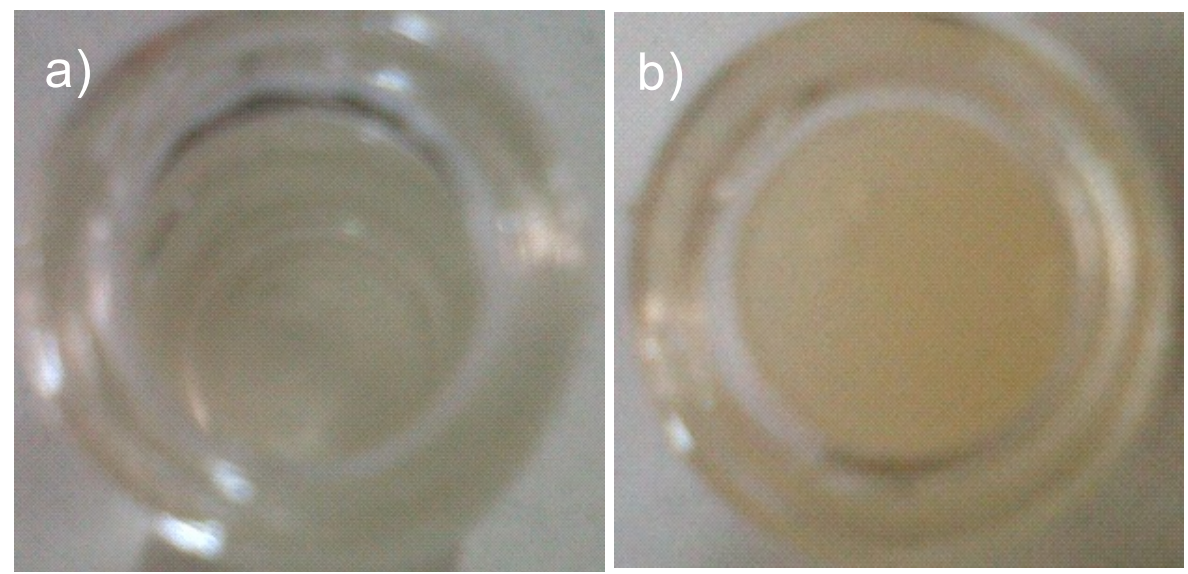

Gambar 5. CNO terhidrogenasi a) tanpa katalis b) dengan katalis PG-Ni

\section{KESIMPULAN}

Dendrimer dengan bentuk unik dimana disetiap ujung struktur melekat gugus fungsi yang aktif dapat dijadikan sebagai penyangga katalis logam. Produk gliserol dari turunan kelapa sawit yang tersedia banyak di Indonesia dapat dijadikan sebagai bahan baku pembuat dendrimer poligliserol. Pada penelitian ini dari hasil uji dengan LC-MS diketahui bahwa produk poligliserol yang dihasilkan berupa tetrapoligliserol (satu inti dan tiga gugus fungsi). Dari hasil uji dengan FTIR diketahui bahwa terbentuknya poligliserol ditandai dengan munculnya puncak pada panjang gelombang $1600 \mathrm{~cm}^{-1}$ yang mengindikasikan gugus $\mathrm{C}=\mathrm{O}$ atau $\mathrm{O}-\mathrm{C}-\mathrm{C}$ dan poligliserol amin pada panjang gelombang $1303 \mathrm{~cm}^{-1}$ yang merupakan gugus $\mathrm{N}=\mathrm{O}$.

Dari foto SEM diketahui katalis Ni yang dihasilkan berbentuk bulat seragam bentuknya dibanding katalis $\mathrm{Cu}$. $\mathrm{Hal}$ ini karena kandungan klorin yang tinggi pada katalis $\mathrm{Cu}$. Pada percobaan penerapan katalis $\mathrm{Ni}$ pada proses hidrogenasi menunjukkan bahwa katalis $\mathrm{Ni}$ dapat berfungsi dengan menghasilkan minyak terhidrogenasi yang mendekati standar industri.

UCAPAN TERIMA KASIH 
Penulis menyampaikan terima kasih kepada Kepala Badan Penelitian dan Pengembangan Industri Kemenperin dan Kepala Balai Besar Kimia dan Kemasan yang sudah memfasilitasi pelaksanaan penelitian ini. Terima kasih yang dalam kepada rekanrekan analis yang sudah membantu dalam terlaksananya penelitian ini.

\section{DAFTAR PUSTAKA}

Boudou, J., M.O David, V. Joshi, H. Eidi, and A.A Curmi. 2013. Hyperbranched polyglycerol modified fluorescent nanodiamond for biomedical research. Diamond and Related Materials 38:131-138.

Cheng, Y., J. Wang, T. Rao, X. He, and T Xu. 2007. Pharmaceutical applications of dendrimers: promising nanocarriers for drug delivery. Frontiers in bioscience: a journal and virtual library 13:1447-1471.

Ciriminna, R., C.D Pina, M. Rossi, and M. Pagliaro. 2014. Understanding the glycerol market. European Journal of Lipid Science and Technology 116 (10):1432-1439.

de Queiroz., A.A. Alencar, G.A Abraham, M.A.Pires Camillo, O.Z. Higa, G.S. Silva, M. Del Mar Fernández, and J.S. Román. 2006. Physicochemical and antimicrobial properties of boroncomplexed polyglycerol-chitosan dendrimers. Journal of Biomaterials Science, Polymer Edition 17 (6):689707.

Gunstone, F., and M. Heming. 2004. Glycerolan important product of the oleochemical industry. Lipid Technology 16 (8):177-179.

Hajji, C., and R. Haag. 2006. Hyperbranched polymers as platforms for catalysts. In Dendrimer Catalysis, 149-176. Springer.

Jiang, Y., and Q. Gao. 2006. Heterogeneous hydrogenation catalyses over recyclable $\mathrm{Pd}(0)$ nanoparticle catalysts stabilized by PAMAM-SBA15 organic-inorganic hybrid composites. Journal of the American Chemical Society 128 (3):716-717.

Kesharwani, P., K. Jain, and N. K. Jain. 2014. Dendrimer as nanocarrier for drug delivery. Progress in Polymer Science 39 (2):268-307.

Klajnert, B., and M. Bryszewska. 2000. Dendrimers: properties and applications. Acta biochimica polonica 48 (1):199-208.

Lestari, H.D. 2006. Sintesis Katalis Ni/Mo untuk Hydrotreating Coker Nafta, Tesis, Program Studi Teknik Kimia Institut Teknologi Bandung.

Mamiński, M., P.G. Parzuchowski, A. Trojanowska, and S. Dziewulski. 2011. Fast-curing polyurethane adhesives derived from environmentally friendly hyperbranched polyglycerols-The effect of macromonomer structure. biomass and bioenergy 35 (10):4461-4468.

Rahayu, M. 2005. Teknologi Proses Produksi Biodiesel. Proses Pengembangan Biofuel Sebagai Substitusi Bahan Bakar Minyak :17-28.

Schmitt, J., and H.C Flemming. 1998. FTIRspectroscopy in microbial and material analysis. International Biodeterioration \& Biodegradation 41 (1):1-11.

Slagt, M. Q., S. E. Stiriba, H. Kautz, R JM. K. Gebbink, H. Frey, and G. van Koten. 2004. Optically active hyperbranched polyglycerol as scaffold for covalent and noncovalent immobilization of platinum (II) NCN-pincer complexes. Catalytic application and recovery. Organometallics 23 (7):1525-1532.

Trollsås, M., and J. L Hedrick. 1998. Dendrimer-like star polymers. Journal of the American Chemical Society 120 (19):4644-4651.

Wijngarden, RJ., A. Kronberg, K.R. Westerterp, and E Schwab. 2000. Industrial Catalysis. Angewandte Chemie-International Edition In English 39 (2):418-418.

Republika. 2015. Indonesia tak Perlu Impor Katalis. Senin, 02 March 2015, http://www.republika.co.id/berita/ekon omi/korporasi/15/03/02/nkkt88indonesia-tak-perlu-impor-katalis

Purwanto, W., M. Nasikin, E. Saputra, dan L. Song. 2010. Production Hydrogen And Nanocarbon Via Methane Decomposition Using Ni-Based Catalysts; Effect Of Acidity and Catalyst Diameter. Makara, Teknologi, 9 (2), hal 48-52.

Rahmi, D., E. Ratnawati, R. Yunilawati, and A. Riyanto. 2014. The Synthesis Of Dendrimer Tetraglycerol From Glycerol Oil Palm Based For Catalysis Process. Proceedings of International Oil Palm Conference, Bali Nusa Dua Convention Center - Indonesia IOPC . 